\title{
Title: Scientists Reflect on Why They Chose to Study Science
}

\author{
Authors: Grady Venville ${ }^{1}$, Léonie Rennie, ${ }^{2}$ Colin Hanbury ${ }^{3}$ \& Nancy Longnecker ${ }^{3}$ \\ ${ }^{1}$ Graduate School of Education, University of Western Australia \\ ${ }^{2}$ Science and Mathematics Education Centre, Curtin University \\ ${ }^{3}$ School of Animal Biology, University of Western Australia
}

Corresponding Author: Grady Venville

email: Grady.venville@uwa.edu.au

Phone: +61864883811

Graduate School of Education

University of Western Australia

35 Stirling Highway

Crawley WA 6009

Australia

Keywords: attitudes, scientists, career pathway, selecting science subjects

Acknowledgements: The research presented in this paper was supported by a Linkage grant from the Australian Research Council (LP0989409), with Scitech and Chevron as industry partners. The views expressed are those of the authors.

Research in Science Education (RISE) 2013. 


\title{
Scientists Reflect on Why They Chose to Study Science
}

\begin{abstract}
A concern commonly raised in the literature and in the media relates to the declining proportions of students who enter and remain in the "science pipeline," and whether many countries, including Australia and New Zealand, have enough budding scientists to fill research and industry positions in the coming years. In addition, there is concern that insufficient numbers of students continue in science to ensure an informed, scientifically literate citizenry. The aim of the research presented in this paper was to survey current Australian and New Zealand scientists to explore their reasons for choosing to study science. An online survey was conducted via a link to SurveyGizmo. The data presented are from 726 respondents who answered 22 forced-choice items and an open-ended question about the reasons they chose to study science. The quantitative data were analysed using $t$-tests and analyses of variance (ANOVA) followed by Duncan's multiple range tests, and the qualitative data were analysed thematically. The quantitative data showed that the main reasons scientists reported choosing to study science were because they were interested in science and because they were good at science. Secondary school science classes and one particular science teacher also were found to be important factors. Of much less importance were the prestige of science and financial considerations. The qualitative data expanded on these findings and showed that passion for science and/or curiosity about the world were important factors and also highlighted the importance of recreational pursuits, such as camping when a child. In the words of one respondent, "People don't go into science for the money and glory. It's passion for knowledge and science that always attracted me to the field".
\end{abstract}

\section{Research Rationale: Choosing Science}

Over the last decades, a plethora of reports and position papers have been released arguing the importance of science education, not only because a continuing supply of science, mathematics, engineering and technology (STEM) workers are required to fill positions in research and industry, but because there is an increasing need for citizens to have sufficient understanding of the science-related complexities of their everyday lives to participate in decision-making about various local and global issues. Some of the well-cited reports include Beyond 2000: Science education for the future (Millar \& Osborne, 2001) and Science and Innovation Investment Framework: Next Steps (HM Treasury, 2006) from the UK; Rising above the Gathering Storm (National Academy of Sciences: Committee on Science, Engineering, and Public Policy, 2006) and Before It's Too Late (National Commission on Mathematics and Science Teaching for the $21^{\text {st }}$ Century, 2000) from the USA; Europe Needs More Scientists (European Commission, 2004) from Europe; The Status and Quality of Teaching and Learning of Science in Australian Schools (Goodrum, Hackling \& Rennie, 2001) and Inquiry into the Promotion of Mathematics and Science Education (Education and Training Committee Parliament of Victoria, 2006) from Australia; Inspired by Science (Bull, Gilbert, Barwick, Hipkins \& Baker, 2010) from New Zealand; the OECD's Evolution of Student Interest in Science and Technology Studies (OECD Global Science Forum, 2006) and UNESCO's Science Education Policy-making (Fensham, 2008). A common theme of these reports is the quality of science education in schools. Declining enrolments at the senior school level are attributed to overloaded science curriculum and transmission teaching 
methods, resulting in disinterested students who are disinclined to pursue science-related careers. Students' attitudes toward and about science are thus perceived as central to these arguments.

In 2012, Australia's current Chief Scientist, Professor Ian Chubb, commissioned a report that confirmed that a higher proportion of high school students need to be attracted into sciencebased subjects to improve the flow through school into science at university and sciencerelated careers, and to contribute to increased scientific literacy in the community (Office of the Chief Scientist, 2012). Comments by Chubb to the Australian Newspaper's Higher Education Supplement (Rowbotham, 2012) indicate tension he observed between allowing students to select their own subjects and the national interest of ensuring Australia doesn't lose its knowledge base in physics, mathematics and statistics. "[The national interest is] too important to leave to the study choices of incoming undergraduates" (p. 37), he said, but "you can't say to them 'You are not allowed to do this and you have to do that"' (p. 37). Rather, Chubb suggested that we have to find other ways to ensure the Australian science-based knowledge and workforce is secure into the future.

In New Zealand, a paper commissioned by the Royal Society and the Prime Minister's Chief Science Advisor (Bull et al., 2010) addressed the matter of better engaging school students in science. The authors' summary of evidence found that a high proportion of New Zealand students did not wish to continue with science beyond the compulsory years. Although top students were performing well, there was ambivalence in taking up science careers, and in New Zealand, as elsewhere, students were making up their mind about interest in science well before the point at which they could choose science.

There is similar and considerable interest in other developed countries in the measurement of students' attitudes toward science and school science and insights which might help to provide information on ways of addressing concerns about declining student attitudes toward science and science-related careers (Tytler \& Osborne, 2012). The reports document the importance of addressing issues of students' attitudes toward science.

Osborne, Simon and Collins (2003, p. 1073) noted that while "the body of research conducted has been good at identifying the problem [about students' attitudes], it has had little to say definitively about how the problem could be remedied" (p. 1073). Accordingly, the rationale for the research presented in this paper was to take a positive approach to the problem referred to by Osborne and colleagues by looking at the reasons why current scientists studied science rather than why other people did or do not. In other words, we have narrowed our focus to those people who have successfully negotiated the leaky pipeline to a science-based career to ascertain the factors that were important for them in the process of their education.

\section{Research purpose}

The purpose of this research was to explore current Australian and New Zealand scientists' retrospective perspectives on why they chose to study science. Our aim was to generate knowledge about how the problem of poor student attitudes about science and declining proportion of people progressing through the science pipeline might be addressed.

More specifically, the research questions were:

1. What factors do current Australian and New Zealand scientists report influenced them to study science? 
2. How do scientists perceive the relative degree of influence of each of these factors?

\section{Conceptual framework}

Why students pursue science subjects in their education and/or select science-related career pathways have been examined from several different theoretical perspectives. The main themes from the literature revolve around students' achievement in science, their attitudes toward science in general and as a subject, students' school experiences of science, the influence of parents and family culture on students' subject choices, and students' perceptions of scientists and their personal identity. While these themes are not mutually exclusive, each is considered in more detail in the subsections of this literature review. Collectively, the themes formed the conceptual framework for this research.

\section{Relationships between attitudes toward science, achievement in science and aspirations to a science career}

There is a strong argument in the literature that ensuring the flow through the pipeline to science-based subjects in tertiary education and science-related occupations depends on school students' attitudes toward science (Tytler \& Osborne, 2012). It is important to note that a number of researchers distinguish between different types of attitudes, including attitudes toward science in society, attitudes toward school science, and attitudes toward a science career (Barmby, Kind \& Jones, 2008). Tytler and Osborne (2012) argue that it is "the perceptions of school science and attitudes toward undertaking a further course of study, which are likely to be most significant in determining students' decisions about whether to proceed with further study of science beyond compulsory courses" (p. 598).

Several large international testing programs that regularly measure student achievement in science have, on a less frequent basis, included measures of students' attitudes toward science with interesting comparisons. For example, the findings from the Programme for International Student Assessment (PISA) 2006 survey gives greater insight into students' attitudes, engagement and motivation in science (Telford \& Caygill, 2007; Thomson \& De Bortoli, 2009) than the more recent PISA 2009 (Thomson, De Bortoli, Nicholas, Hillman \& Buckley, 2011). In the 2006 PISA, both New Zealand and Australian Grade 10 students performed well on the tests for scientific literacy, significantly higher than the OECD average. Of the 57 participating countries, only Finland and Hong Kong-China performed significantly better than New Zealand, and Finland, Hong Kong-China and Canada performed significantly better than Australia.

In the measure of general interest in learning science, however, Australian students, together with students from the Netherlands, Finland and Korea, had the lowest average scores of the 57 countries. New Zealand students scored higher on general interest, but still below the OECD average. Thomson and De Bortoli (2009) concluded that "clearly lack of interest is no handicap to performance, nor is interest a guarantee of high levels of performance" (p. 123). Both Australian and New Zealand Grade 9-10 students were found to be more instrumentally motivated than the OECD average; that is they were more likely to make an effort in science because they know it is 'good for them' in terms of what they might want to study later on or do as a career (Thomson \& De Bortoli, 2009). Similarly, the PISA results indicated that New Zealand students' intentions to pursue science in the future were about the same as other OECD countries, and they expected science to be useful to them (Telford \& Caygill, 2007, p. 16). However, on average, Australian students were a little less likely than the OECD average to "expect to have a science-related career or complete further study in the areas of science after secondary school" (Thomson \& De Bortoli, 2009, p. 132). 
Gender differences in the Australian and New Zealand results on the 2006 PISA scales were trivial, with only the small differences between boys' and girls' enjoyment of science reaching statistical significance in both countries, and a future-oriented motivation to learn science in Australian results (Thomson \& De Bertoli, 2009). In these cases, boys scored more positively than girls. The 2009 PISA results measured only scientific literacy, not attitudes, and again gender differences in achievement were trivial and not statistically significant (Thomson et al., 2011).

The Trends in International Mathematics and Science Study (TIMSS) in 2007 was conducted with children in Grade 4 (Grade 5 in New Zealand) and Grade 8 (Grade 9 in New Zealand). Findings indicated that Australian Grade 4 students achieved above average overall, and had the same positive attitudes toward science as the average for the 36 participating countries (Thomson, Wernet, Underwood \& Nicholas, 2007). In contrast, the achievement of Grade 8 Australian students was only just above average, and their level of interest much lower than the average for attitudes toward science of the 49 countries participating in TIMSS at Grade 8. As with the Grade 4 students, the Grade 8 students at the high level on the measure for attitudes toward science in the TIMSS study had significantly higher average science achievement compared with those at the medium and low levels. New Zealand students had lower science achievement than Australia at this Grade 5 level, but had more positive attitudes toward science (Bull et al., 2010; Caygill, 2008). New Zealand did not participate at the Grade 9 level in 2007.

The findings from PISA and TIMSS, described above, demonstrate an interesting difference in trends 'between country' and 'within country' with regard to attitudes toward science and achievement in science (Bybee \& McCrae, 2011). When different countries are compared, students in countries with higher average achievement in science tend to have lower average attitudes toward science (a negative correlation). In contrast, within Australia and NZ, students with higher average achievement in science tend to have better attitudes toward science (a positive correlation). In both Australia and New Zealand there were no statistically significant gender differences in achievement. Also in both countries, there was a strong positive relationship between socioeconomic background and achievement in both PISA and TIMSS (Bull et al., 2010; Caygill, 2008; Telford \& Caygill, 2007; Thomson \& De Bertoli, 2009; Thomson et al., 2007; Thomson et al., 2011).

There have been a number of studies conducted with children in school on their future science and mathematics aspirations. For example, Tai, Liu, Maltese and Fan (2006) reported a longitudinal study in the USA that asked 8th graders their career expectations in 1988 and then compared their actual tertiary study choices in 2000 for the subset for whom they had complete data $(\mathrm{N}=3,359)$. Those who had anticipated a career in science were more likely to graduate from college with a science degree than those who did not. This relationship was particularly strong for those with physics and engineering degrees. The authors claim their findings emphasise the importance of exposure to science and encouraging interest in science in the middle school and younger grades.

Riegle-Crumb, Moore and Ramos-Wada (2011) used USA data from the 2003 TIMSS from Grade 4 and Grade 8. Surprisingly, they found that Black and Hispanic adolescent boys had comparable aspirations toward future careers in science and mathematics as their White male peers, despite large differences in achievement. In contrast, they found that White and Hispanic females were only half as likely as White males to aspire to mathematics-based 
occupations, and that "it appears that enjoyment of science is perhaps an important driver behind gender difference in career aspirations at younger ages, at least in the case of White and Hispanic girls" (p. 472).

Kim and Song (2009) examined the relationships between attitudes and conceptual understanding of physics in Japanese high school students. Using a structural equation modelling methodology, they found that the Grade 10 students' attitudes toward school science and interest in the science subject matter, as opposed to how important students perceived science is to society, "exclusively" (p. 2401) influenced students' conceptual understanding of physics. Further, they found that through "reluctant persuasions" students might "temporarily" accept the importance of science in society and "superficially" learn concepts while they study science in high school (p. 2401).

In a longitudinal study of 7649 British students aged over 17 years, Schoon (2001) found that the factors most likely to predict a career in science included: the students' occupational aspirations at age 16; their belief in their own scientific ability; their teachers' rating of their scientific ability; and, their actual mathematics ability. Overall, fewer females than males aspired to be scientists, and fewer achieved this goal. Schoon concluded that the best time for encouraging females' interests in a science career is when they are at school. Importantly, Schoon found that although only $6 \%$ of those aspiring to be scientists did fulfil their ambition, if the data were considered retrospectively, $37 \%$ of the scientists matched their teenage aspirations. Clearly, contextual factors such as job availability and economic circumstances, as well as aspirations determine future actual careers.

\section{School experiences of science}

As suggested in the previous section, students' experiences of school science are considered to be critical to their attitudes toward further study and careers in science (Schoon, 2001; Tytler \& Osborne, 2012). One retrospective study conducted by interviewing English students who had recently made their post-16 subject choices (Pike \& Dunne, 2011), found that their reasons for selecting particular pathways were complex but that dominant themes portrayed in the students' interviews were pedagogical experiences, school-determined streaming or differentiation and their own understandings of future educational and occupational pathways in a changing labour market. According to Pike and Dunne, the students' reflections "universally" (p. 491) indicated the importance of secondary school experiences in shaping how they identified with curriculum subjects, such as science and mathematics, and whether they considered these subjects as part of their future. Traditional pedagogies often used in science classes and the perception by students of a lack of relevance of science subject matter resulted in science being unpopular with the students. The students also put mathematics and science at the top of what the researchers referred to as a "subject hierarchy" (p. 491) of difficulty and evaluated themselves as either capable or not capable of further studies of science. The researchers concluded that "the main threads that run through these quotes show that they [students] choose subjects that they both enjoy and are successful at" (p. 492).

Another retrospective interview study of scientists and graduate students by Maltese and Tai (2010), which followed the Tai et al. (2006) study, found that for $65 \%$ of participants, interest in science began in middle school or earlier. Further, interest in science for $40 \%$ of participants was attributed to experience(s) at school, such as teacher demonstrations or projects, or participation in educational events related to science. Intrinsic interest in science was indicated by $45 \%$ of participants to be their reason for pursuing a science-related career. 
These results were different for males and females, however, with $57 \%$ of males and only $24 \%$ of females mentioning intrinsic interest as the major driver, and $52 \%$ of females compared to $33 \%$ of males attributing their interest to school-related experiences.

Barmby et al. (2008) found in their study with 932 English students that their attitudes toward science in general declined as they progressed through secondary school, a finding consistent with the TIMSS results in Australia described above, and also findings in New Zealand (Bolstad \& Hipkins, 2008). In addition, they found that this decline was strongest for the construct related to students' attitudes toward learning science at school. Moreover, through linear regression they found that as students progress through school, the construct of attitudes toward learning science at school had greater influence on their attitudes toward science in general. Interviews revealed that the students found school science impractical, not well explained and irrelevant. Their main recommendation was "the need to concentrate on improving pupils' experience of science in school” (Barmby et al., 2008, p. 1089).

The practical aspects of school science, such as doing experiments, often are considered to be motivating and interesting for many students. Abrahams (2009) examined the relationship between practical work in science classrooms and affective outcomes for 11- to 16-year-old students in 25 multi-site case studies in English comprehensive (non-selective) schools. Contrary to popular belief, Abrahams found that while practical work brought about shortterm engagement, it was ineffective in motivating the students to select science as a postcompulsory course or engender longer-term personal interest in science subjects.

Recent reports commissioned in Australian and New Zealand (Bull et al., 2010; Office of the Chief Scientist, 2012; Universities Australia, 2012) all concluded that students' experiences in school science resulted in the lack of interest and engagement that underpins their reluctance to continue in science beyond the compulsory age. Fensham (2008), in a policy paper commissioned by UNESCO, summarised the matter thus: "It is urgent that education policy makers address the lack of engagement that so many students experience in school science and technology education" (p. 20).

\section{Influence of parents and family culture}

Students are considered to be strongly influenced by their parents in their subject and career choices. In Canada, for example, researchers (Adamuti-Trache \& Andres, 2008) used longitudinal data over 10 years with 1,055 respondents and found that students with university-educated parents were more likely to complete science courses in high school and had earlier plans to continue post-secondary education. These early decisions put students with university educated parents at an advantage for the long trajectory into science-related careers. Adamuti-Trache and Andres discussed this phenomenon from Bourdieu's cultural reproduction perspective, that is, that parents transmit capital in the form of dispositions, habits and attitudes to their children and that this results in the reproduction of current inequalities in education and social status. They argued that the educated parents of the respondents in their study understood the future worth of various types of academic subjects and influenced their children's academic choices. This type of "push" (p. 1576) is referred to as cultural capital. Adamuti-Trache and Andres concluded that the intersection between institutional and disciplinary structures with the cultural capital transmitted by the family shaped the opportunities and access to scientific fields for both girls and boys.

Young (2008) argued that the differentiation of the curriculum in many countries over the past 25 years to include subjects that are more "context driven, problem focused, and 
interdisciplinary" (p. 8) compared with the traditional disciplinary mode that is "academic, investigator initiated, and discipline-based" (p. 8) was misplaced. He contended that while this move was, at the time, thought to provide access to education for traditionally under privileged and marginal groups, it has resulted in the perpetuation of inequalities and discrimination against these groups. Young explained that by giving students more choices about the types of subjects they might study at school, they are able to make poor choices that result in truncated educational opportunities and career trajectories. In particular, students from disadvantaged backgrounds, with poor families, and/or uneducated parents, for example, lack the "cultural resources" (p. 10) to make appropriate educational choices. Young argued that children who come from elite family cultures are more likely to be able to select wisely to acquire what he terms "powerful knowledge" (p. 15) that enables them to progress along educational pathways that provide them with choices and, ultimately, economic and social advantages.

Research by Sonnert (2009) with American scientists concluded that females more than males were likely to cite parental influence in their choice of science, but that fathers rather than mothers were more likely to be mentioned as the influencers. This interesting interaction between the gender of scientists and parental influencers conflicts with a role-model hypothesis of influence. Among the scientists and graduate students interviewed by Maltese and Tai (2010), $10 \%$ of males compared to $24 \%$ of females attributed their interest in science to family members. This result is consistent with Sonnert's (2009) finding, but Maltese and Tai did not report on which family member was supportive; rather they found that the majority of participants referred to unconditional support from family for their career choices.

Over nearly four decades a great deal of research related to social and motivational factors affecting achievement goals and career aspirations and choices, particularly in mathematics, science and more recently computer-related careers, has been carried out using the Expectancy Value Model originating with Eccles and her colleagues. Eccles (2009) provides a retrospective account and a representation of the model in the process of a person's enactment of personal and collective identities and their motivational role in the making of behavioural choices. For example, because of expectations related to gender roles parents may give different messages to, and provide more opportunities for, boys compared to girls relating to engagement in mathematics and science. The outcomes are gender differences in educational and occupational choices. Bøe, Henriksen, Lyons, and Schreiner (2011) conducted an analysis of research into young people's participation in STEM fields by using Eccles' expectancy value model, supplemented by more recently articulated sociological perspectives to provide a cultural, rather than a psychological context. Bøe et al. concluded that the Eccles' model was a useful lens to view occupational choices in STEM, and that efforts to increase the interest-enjoyment value, attainment value, and utility value of STEM subjects could reduce impediments to participation in STEM careers.

\section{Perceptions of scientists and science occupations}

Negative perceptions of scientists as boring and unattractive are considered to be a factor that puts students off the idea of a science-based career. One study of students' attitudes toward science careers (Masnick, Valenti, Cox \& Osman, 2010) found that their participating high school and college students in the USA across age and sex "considered scientific professions to be less creative and less people-oriented than other popular career choices" (p. 653). They concluded that students may be led away from potential science-related careers by misperceptions that "science is a difficult, uncreative, and socially isolating pursuit" (p. 653). This study presents an interesting contrast with another where the researchers (Lunn \& 
Noble, 2008) worked alongside scientists to produce visual and oral narratives based on everyday realities of real, contemporary scientists. They found the pervasive theme to emerge was the link between art and science, and that "the contemporary story of science can encompass wonder, love, and passion in the scientific imagination" (p. 803). Lunn and Noble argued that a science curriculum that reflected their research findings would present science to secondary school students as an holistic, creative, and innovative field of study. They also claimed that such a move would have the potential to inspire greater participation in the sciences.

\section{Informal science experiences}

It is well documented that in addition to formal education in school settings, students can learn about and develop attitudes toward science through informal learning contexts such as science centres, museums, community organisations and the mass media (Rennie, 2007; Stocklmayer, Rennie \& Gilbert, 2010; Tal, 2012). Compared with formal, school environments, learning in informal (sometimes referred to as 'out-of-school') contexts is usually learner-led and intrinsically motivated (Rennie, 2007). Characteristics of informal science programs are that they are usually voluntary and students are often given choices as to the direction and content. Further, the programs are not assessed and can be delivered to students of a range of ages and abilities (Tal, 2012; Wellington, 1990).

The quantity of research that investigates science learning and the development of attitudes toward science in informal contexts is considerably less than that conducted in formal school settings (Osborne \& Dillon, 2007). Research within Australia suggests that outreach programs offered by science centres and other providers increased students' interest and skills and benefited students and teachers by demonstrating new approaches, content, techniques and resources (Garnett, 2003). However, while participants are generally positive about the experience, it is a paradox that it is unlikely that the potential of these incursions into schools are fully realised in terms of student learning of science (Rennie, 2007). One informal program provided by Questacon, The National Science and Technology Centre in Australia, called "Smart Moves" aims to raise the awareness of secondary school students in regional and rural Australia concerning innovative Australian science and technology and emerging career opportunities. Lucas (2004) conducted an evaluation and the findings suggest that the Smart Moves program is effective in raising or confirming pre-existing interest of a minority of students in pursuing careers in science and/or technology. Interest also is aroused in other students attending the presentation but, for most, this dissipates rapidly after the presentation in the absence of appropriate supporting activities.

Tytler and Osborne (2012) note that more attention needs to be given to educating students about the career pathways available to them through studying science. They draw attention to the obvious: Students can't aspire to something they don't know about.

\section{Methods}

The purpose of this research was to explore the reasons that current scientists give as to why they chose to study science. In other words, we set out to describe how a present condition was influenced by previous events or conditions (Cohen, Manion \& Morrison, 2011), so the method of data collection was an online, retrospective survey. Specifically, the research was designed to study how people who have at least a bachelor of science qualification or equivalent perceive they were influenced when they were selecting science subjects and 
educational pathways. In this paper we report the results from citizens of Australia and New Zealand.

Cohen, Manion and Morrison (2011) and Fowler (2009) outlined the potential advantages, problems and solutions associated with online surveys. The advantages include reduced cost and time for distribution, enabling a much wider population to be accessed. Online surveys enable the respondent to complete the questionnaire from a place and at a time convenient to them. Moreover, the use of the computer improves completion rates, reduces researcher effects and missing entries as well as human error in entering and processing the data. These factors all contributed to our decision to use an online survey, rather than a face-to-face or paper-based survey, or interviews, as our main data collection tool.

Despite these advantages, there are a number of problems with online and retrospective surveys. For example, Fowler (2009) noted that, as with paper-based surveys, the disadvantages of not having an interviewer involved can affect the quality of the data collected. To address this problem, we conducted interviews with scientists to improve the quality of our survey items (see more detail below). Cohen et al. (2011) also referred to potential technical issues with regard to the hardware and software, and also with the respondents' computer-based expertise. To avoid these technical issues, we used a readily available and widely used survey tool, SurveyGizmo (www.surveygizmo.com). Further, our target population comprised people very likely to be expert in the use of computers.

Cohen et al. (2011) cautioned about the possibility of respondents answering the survey more than once, that they may not tell the truth, and they may lose interest and abandon the survey, thereby losing data. While we can see these problems may be relevant to some online surveys, we could not think of any reason why our respondents would answer the survey more than once, or any widespread reason why they would be motivated to not tell the truth. Rather, we felt that many current scientists would be interested in the accurately reported findings of our research and that this would motivate them to be as honest as possible in their responses. We noticed that some respondents omitted some questions, but due to the convenience of the computer generated data, we were able to report the exact percentages of the total number of respondents for each item. One of the potential weaknesses of our use of an online, retrospective survey was the accuracy of the respondents' memories. Two longitudinal studies reported in the literature review above, Tai et al. (2006) and Schoon (2001), found that young adolescents' career expectations were reasonable predictors of their study choices later in school and college and their actual careers. These findings gave us more confidence in the retrospective nature of our survey.

Sampling bias is a concern for all surveys (Fowler, 2009), but whether or not an online survey accentuates sampling bias compared with other surveys is contentious. On the one hand, Cohen et al. (2011) explained that sampling bias can be a major concern for online surveys because it tends to tap into middle-class and well-educated populations. On the other hand, Cohen et al. argued that the increased uptake of the internet by a wide spectrum of people in recent years has reduced this potential sample bias and that online surveys can now allow greater generalizability because internet users come from a wide and diverse population. In addition, the voluntary participation in online surveys reduces the possibility of coercion and as such, greater authenticity of responses can be obtained. Importantly, our target audience of people with a bachelor of science includes individuals who are likely to have access to the internet and also to have sufficient expertise to respond to the standard online survey we selected. 
Cohen et al. (2011) explained that a major problem for online surveys is estimating the size and nature of the population from which the sample was drawn. The issue is that researchers using online surveys usually rely on a non-probability, volunteer sample, and this may decrease the generalizability of the findings. In this research, we were able to estimate the total population of people with a bachelor of science or equivalent in Australia and New Zealand. The Australian Bureau of Statistics conducted a census of the Australian population in 2011 (http://www.abs.gov.au). Data from the 2011 census revealed that $18.8 \%$ or a total of 3,268,912 Australian people 15 years of age or older had a bachelor degree or higher as their highest level of education. In New Zealand the census scheduled for 2011 was not conducted due an earthquake in Christchurch. However, 2006 census data from Statistics New Zealand (http://www.stats.govt.nz) showed that 422,179 , or $16 \%$ of people aged 15 years or older, had a bachelor degree or higher. Based on information on fields of study from the Australian 2011 census data, we estimated that a quarter of these people would have studied a bachelor of science or related field. In this way, we estimated that during the period of data collection there was approximately 820,000 people in Australia and 106,000 people in New Zealand (total: 926,000 people) with a bachelor of science degree or higher qualification in science or a related field.

\section{Development of the survey}

The five different themes from the literature reviewed above provided the conceptual framework from which the survey questions for the scientists were developed. The clusters included personal factors, school-related factors, informal science experience factors, science career-related factors; and factors related to family and friends. Face-to-face interviews with eight Australian male and female scientists of different ethnic backgrounds and ages provided terms and specific words that could be used to enhance the suitability of the items to the target participants. The initial items were developed by one member of the research team and critically reviewed by the other members including two experts in science education and one in science communication. A draft of the survey was trialled with 10 postgraduate students in a science communication program who provided feedback on wording, layout, readability and content of the items.

The final survey questions elicited general demographic information, such as the respondents' own and parents' educational levels, as well as their reasons for choosing to study science, current job-related information and views on job future and on science in society more generally. This paper focuses on scientists' reasons for choosing to study science. There were 23 questions concerning the participants' reasons for choosing to study science. Twenty two of these questions employed a Likert scale format and one was an openended question, that is, respondents were able to type in their own response. An additional question asked respondents at what age they realised they were interested in studying science. The wordings of the 22 Likert questions were developed within the five general categories of influence described above. The eight possible responses to these questions were: significant negative influence, moderate negative influence, slight negative influence, no influence, slight positive influence, moderate positive influence, significant positive influence, or not applicable. These questions were analysed quantitatively. The open-ended question read, "Was there an important influence on you to study science that was not covered in the series of questions above?" The qualitative responses to this item were analysed thematically.

\section{Administration of the survey}


The online survey was conducted internationally via a link to SurveyGizmo (www.surveygizmo.com) and took approximately 15 minutes for a respondent to complete. In total there were 1885 respondents from citizens of 90 countries. The data reported in this paper are a subset of the total dataset. This subset consisted of 648 respondents who were citizens of Australia and 78 who were citizens of New Zealand (total $n=726$ ); of these $86.6 \%$ were resident in Australia, 8.2\% in New Zealand, and the remainder in one of 16 other countries. The prerequisite for responding to the survey was the completion of the equivalent of a degree qualification in science or applied science (e.g., bachelor degree) requiring at least three years of full time tertiary study. Cohen et al. (2011, p. 147) recommended that for a population of one million (our estimate was 926,000 - see above), a confidence level of $95 \%$ and a confidence interval of $4 \%$, a minimum sample of 600 should be attained. The total of 726 Australian and New Zealand respondents met this requirement for a probability sample and, therefore, we can have confidence in our results, plus or minus $4 \%, 95 \%$ of the time.

Cohen et al. (2011) recommended using a combination of an online survey with emails as a method of contact in order to maximise response rates from potential participants. The respondents in this study were contacted mostly by email via a range of professional organisations, email groups, institutional links and personal contacts. There were approximately 300 contacts made: $28 \%$ to university or government departments, $22 \%$ to science-based organisations, $9 \%$ to not-for-profit science organisations, $5 \%$ to science promotion organisations, $3 \%$ to science blogs and $1 \%$ to science publications. In total, 1848 respondents indicated how they had found out about the survey: $45 \%$ by email, $43 \%$ from a friend or colleague, $7 \%$ by online links, $3 \%$ by blog, $2 \%$ from a publication and $1 \%$ by social media.

\section{Quantitative data analysis}

For the purposes of statistical analysis, the seven response choices to each of the 22 items on the Likert scale were scored $-3,-2,-1,0,1,2$ and 3 respectively. Respondents indicating "not applicable" were excluded from the analysis for that particular item and there were also a small number of omissions on each item, consequently the number of responses analysed for each item varies between 554 and 719. Descriptive analysis was performed using Genstat Version 12.1.0.3338 (www.vsni.co.uk), and statistical analyses included $t$-tests and analyses of variance (ANOVA) followed by Duncan's multiple range tests, a multiple comparison procedure that uses the studentised range statistic $\left(\mathrm{q}_{\mathrm{r}}\right)$ to compare sets of means (Duncan, 1955).

Consideration was given to collapsing the data using a procedure such as factor analysis, and indeed preliminary cluster analysis indicated interpretable clusters similar to the five factor framework underpinning the items. For example, the five items relating to informal sciencerelated activities each correlated most highly with another. However, it was considered that too much information would be lost because of the diversity of responses. The analyses reported below are based on the responses for individual items, but they are flagged according to whether they are items representing personal, school-related, informal sciencerelated or science career-related factors, or factors related to family and friends. We also conducted a broad scope of analyses based on personal information collected about the respondents, including their sex, age, current occupation and highest degree. We have included some of these findings where interesting patterns were revealed that added value to our conclusions about the research questions. 


\section{Qualitative data analysis}

The qualitative analysis was completed in three stages. First, one researcher read through all responses to the open question, "Was there an important influence on you to study science that was not covered in the series of questions above?" An initial list of 60 words that represented the main ideas from the responses was constructed. These words were arranged into 15 initial categories (coded $\mathrm{A}$ to $\mathrm{O}$ ), and a description developed with four example comments provided for each of the categories to create a coding manual.

In the second stage, three researchers discussed the categories and made minor changes and clarifications before independently coding 43 responses. The three coders all agreed on $72 \%$ of the codes. After examination of the codes where there was disagreement, several changes were made to the coding manual to improve the clarity of code descriptions, one code was split into two, and another added, making a total of 18. One researcher then coded all responses to the open-ended question. Several difficult to code responses were highlighted by this single researcher and discussed amongst the three researchers until a consensus was reached. During this process, an additional category was added to the coding manual for the very few number of responses, usually neutral or ambiguous, that did not make sense to the researchers and could not be classified.

In the third stage, two researchers independently coded 50 randomly chosen comments from the online survey into one of the 18 categories in the coding manual. Of the 50 comments, 42 were placed in the same category by the independent coders, representing an $84 \%$ inter-coder agreement. An example of one of the eight comments on which the coders disagreed was "Working outside". It was difficult to determine whether the respondent meant that an experience working outside had influenced him/her to select science subjects which would put it into Category $\mathrm{H}$, outdoor recreational/lifestyle pursuits; or whether the respondent meant that the possibility of working outside in a science job was appealing to him/her and, therefore, classified in Category $\mathrm{O}$, science work/lifestyle. After discussion a decision was made on the category the coders agreed most closely corresponded with the meaning of the comment. For this example, the coders agreed the comment be classified in Category $\mathrm{O}$, science work/lifestyle. A copy of the final coding manual is provided in Appendix 1.

\section{Findings}

The findings are presented in three subsections. The first subsection describes the demographics of the respondents, including their country of birth, mean age, and sex, as well as information about their education and current work. The second subsection provides findings about the degree to which the participants perceived the 22 pre-identified factors influenced them to study science. The third subsection provides a summary of respondents' qualitative responses to the open-ended question, 'Was there an important influence on you to study science that was not covered in the series of questions above?'

\section{Demographics of respondents}

Of the 726 responding citizens of Australia and New Zealand, 71\% were born in Australia, $10 \%$ in New Zealand and the remainder in 35 other countries. Respondents were 58\% females and $42 \%$ males; women tended to be younger than the male respondents with mean ages of 36 and 45 years respectively.

In terms of their education, $62 \%$ of the respondents received a government-provided school education, $20 \%$ a private education, $10 \%$ a government primary with private secondary 
education, and $7 \%$ received some other mixture of government and private education. There were more privately educated respondents from Australia compared with New Zealand; a statistically significant difference $(p<0.001)$. Of the data presented here, this was the only statistically significant difference between the two countries.

Of the respondents, $80 \%$ had completed their first science qualification in Australia, $10 \%$ in New Zealand, and the remainder had completed theirs in one of 22 other countries. For their bachelor's degree, 77\% completed a Bachelor of Science (BSc), 9\% a Bachelor of Science in Agriculture (BAg), 4\% a Bachelor of Engineering (BEng), and the remainder a range of other qualifications. Higher scientific qualifications had been completed by $67 \%$ of respondents (see Figure 1) and of these $77 \%$ had been completed in Australia, 12\% in New Zealand, and the remainder in one of 14 other countries. $\mathrm{A} \mathrm{PhD}$ was the most commonly completed further qualification, representing over half of those who had completed higher qualifications (Figure 1). The respondents represent a more highly qualified sample than those of science graduates generally in Australia, where $26 \%$ of graduates have a postgraduate degree (i.e., Masters or $\mathrm{PhD}$ ) for those employed in natural and physical sciences (ABS, 2010 - Education and Work Australia, ABS Publication 622, May 2010).

Insert Figure 1 about here.

Respondents working in science-related fields at the time of the survey $(n=623)$ indicated their type of employment (Figure 2). Science research was the most common type of work, followed by applied science and science education at similar proportions. While the other respondents identified themselves as scientists by completing the survey, they were currently employed in roles more related to administration, policy and management.

Insert Figure 2 about here.

The ages at which the respondents recalled they realised they were interested in studying science are shown in Table 1 . The age clusters roughly correspond to stages of education. It can be seen that about a quarter of respondents indicated an age up to 11 years, corresponding to primary school, another quarter between 12 and 15 years, corresponding to lower secondary school, and more than a third in senior secondary school. Only $6 \%$ made their choice in their late teens, and 5\% after reaching 21 years.

Insert Table 1 about here

\section{Quantitative findings about science influences}

A summary of the findings for the 22 items concerning the respondents' reasons for choosing to study science is presented in Figure 3. Interestingly, all questions had net-positive mean scores, ranging from 0.02 for "I wanted to earn more money" to 2.69 for "I was interested in science". The latter question was clearly more important than all other questions to respondents, and given that the maximum score was 3.00, it was clearly a very important reason. Apart from this question which, due to a ceiling effect, had the smallest standard deviation of 0.61 , "school counsellor/counselling" and "family friend", with standard deviations of 0.84 and 0.87 , respectively, all questions had standard deviations exceeding 1.00 , indicating a good deal of diversity in the responses.

The relative influence of the 22 factors was determined by ANOVA followed by Duncan's multiple range tests. Figure 3 graphs the means and reports these test results. It can be seen 
that the two items with lowest mean scores ( 0.02 for "I wanted to earn more money" and 0.06 for "school counsellor/counselling") are not significantly different to 0.00 - the equivalent of "no influence". All other factors can be assumed to have had some influence on at least some respondents. It is notable that the items which attracted large numbers of responses in the "not applicable" choice were items with low mean scores; for example, over $20 \%$ chose "not applicable" for "school counsellor/counselling", and "a scientist I knew".

Insert Figure 3 about here

Five factors had mean scores exceeding 1.5, and can be considered to be the most important influences on choice to study science. The second-highest mean score of 2.04 for "I was good at science" was statistically significantly lower than the highest score of 2.69 for "I was interested in science", and the mean scores of the next three questions were all significantly different from each other. These five questions included three categories, personal, schoolbased ("secondary school classes" and "one particular class teacher"), and informal ("science-based television programs"). There were nine questions which had a mean score that fell significantly below "slightly agree" (i.e., representing a score of 1 on the 7-point scale) and included questions from all categories.

Within the category of Personal Reasons for choosing science, the items in descending order of influence were "I was interested in science", "I was good at science", "I wanted to improve the world", "I wanted to improve my prestige" and "I wanted to earn more money". The mean scores of all items were statistically significantly different from each other, with the last two having the third lowest and lowest mean scores, respectively.

The School-based Reasons for choosing science were widely spread. In descending order of influence were "secondary school science classes" (the third highest mean), "one particular science teacher", "primary school science classes" and, "school counsellor/counselling" (the second lowest mean). There were statistically significant differences between all items.

There were five Informal Reasons for choosing science. In descending order of influence the items were "science-based television programs", "Science books or magazines", "a science centre or museum", "science-based films" and "a science competition or event". Again within this category, the mean scores of all items were significantly different from each other.

Within the category of Career-related Reasons for choosing science, the items in descending order of influence were "I was interested in a particular job", "a scientist I had heard of" and "a scientist I knew". These three items also had mean scores that were significantly different from each other.

Finally, within the Family/friends Reasons for choosing science, the items in descending order of influence were "Father", "Mother", "other family member", "friend of similar age (peer)" and "family friend". All items had mean scores significantly different from each other except "other family member" and "friend of similar age (peer)".

The responses to eight items revealed statistically significant different patterns $(p<.05)$ for males and females of their perceived influences on choosing to study science. The means scores for these items are shown in Figure 4. The results show that interest in a particular job, wanting to improve the world, influences of both parents (but fathers more than mothers), knowing a scientist and participating in a science competition or event, were perceived as 
stronger influences on females than males. Science books and science films were perceived by males to be stronger influences on their choice to study science. Although statistically significant, the Cohen's $d$ effect sizes were small, between 0.16 and 0.32 .

Insert Figure 4 about here

\title{
Qualitative findings about science influences
}

A total of 219 of the 726 participants provided responses to the open-ended question: "Was there an important influence on you to study science that was not covered in the series of questions above?" Of these 219 people, 107 provided a response that included only one extra influence or reason for studying science, 62 provided two extra reasons, 27 provided three extra reasons and 23 provided four extra reasons. This resulted in a total of 404 additional reasons for pursuing science. Analysis of these responses resulted in the identification of a total of 18 categories and these are described with examples in the coding manual (see Appendix 1). Figure 5 provides a histogram of the number of responses classified into each category. The categories are coded into the same themes used in the quantitative data, based on the theoretical framework discussed earlier.

Insert Figure 5 about here

The most common category was "curiosity", with 49 participants listing reasons for pursuing science that related to their curiosity about science-related matters, their fascination with the world or the intellectual stimulation of finding out about the world. Examples of comments in this category included the following:

\author{
Possessing an inquiring mind \\ I wanted to know how the world worked \\ Natural curiosity \\ The World, it's amazing \\ How and why things happen \\ A desire to overcome fuzzy thinking with logic \\ FASCINATION \\ I sensed order in the world and wanted to understand
}

The second most common category of responses to the question was outdoor recreational pursuits (see Figure 5), where 42 participants said they had been involved in activities such as being brought up on a farm, camping, fishing, hiking or star gazing that influenced them to pursue science.

Growing up on a farm
Holidays at a small seaside village
Outdoor activities with friends and family
Learning bush tucker/medicine skills from Aboriginals
Born in a mountain village in a pristine area
Bushwalks with my grandfather and other enjoyment of recreational activities outdoors

Two categories were equal third with responses from 34 participants. One related to interest in a particular aspect of science, for example, mathematics, experiments, or botany, and respondents reported that this particular interest influenced them to study more science. The other with 34 responses was the participants' educational pathway where they explained, for 
example, they were streamed into the science class, or they weren't good at other subjects. The fifth most common category, with 32 responses, was indoor recreational pursuits, including an interest in activities such as reading or watching science fiction, science books, or being given a science toy (Figure 5).

It is interesting that even though participants could select some school-related factors that might have influenced them from the 22 fixed-response questions, 32 participants still opted to type in a response to the open question about a good teacher or university lecturer or great science lessons or fun laboratory activities that were classified under the category 'school/university' factors (Figure 4).

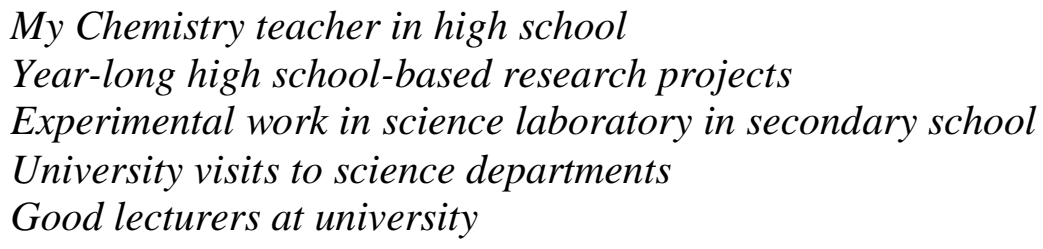

Another interesting finding is 18 participants cited reasons related to environmentalism that had influenced their science choices, for example, climate change had emerged as a threat, or they were concerned about endangered species (Figure 4). Fifteen participants said that lifestyle factors related to science-based careers attracted them, such as travelling the world or field work and another 24 said that they thought that studying science provided them with opportunities for career choices. Sixteen participants mentioned specific science events, such as the Moon landings, the development of computers, or scientists such as Richard Dawkins, as influencing their interest in studying science (Figure 4).

\title{
Other patterns in the qualitative data
}

We noticed some minor trends within the qualitative data that cut across the categories presented in Figure 4. For example, some respondents believed that science is a hard subject that only clever people can do or understand well.

\author{
Most other subjects were too easy/boring for me \\ I believed that if you were good at school you studied something challenging i.e. \\ science \\ It was for gifted children in science and maths \\ Being a 'bright' student, there was an anticipation I would qualify in a difficult subject
}

There also was evidence that people who were not necessarily gifted in science, for one reason or another, 'fell' into science.

\author{
Was not accepted to first choice at university (Music) \\ In preparation to study medicine, but never got in \\ Nothing better to do \\ [The education department] sent me to the wrong school \\ I wasn't keen on languages or the arts \\ Course available locally
}

In contrast with our finding reported above that most respondents knew they were interested in science by the time they were 17 years of age, a small number indicated that it wasn't until they were already in university that their true passion for science became apparent. 
Psychology units while studying for Arts degree

Ifound some interesting units in the university handbook

A specific university science lecturer

Science-based research in my Master's degree

Really enjoyed first year science at uni

This finding raises questions about the most appropriate time to be encouraging interest in studying science that we take up in the following discussion.

\section{Discussion}

\section{Achievement and passion contributing to a science identity}

The main reasons that current scientists in our sample gave for pursuing an education in science were that they were interested in science, they were good at science, and in the openended responses these influences were extended to being curious about the way the world worked, or interested in particular aspects of science. These are personal qualities that reflect what has been referred to in the literature as a 'science identity' (Lee, 2012). Having an identity is having a "subjective sense or definition of oneself" (Lee, 2012, p. 36). In other words, having a science identity is being able to recognise yourself as being a particular type of person, a science type of person, and also being able to recognise who you are not. For school students, having a science identity is having a sense of belonging to and affiliation with science practices and engagement in the learning of science. "Adolescence is a particularly significant time when young people are first confronted by the need to construct their sense of self' (Tytler \& Osborne, 2012, p. 614).

\section{Who studies science subjects?}

The fact that the most significant factors influencing participants to study science on the quantitative questions in the survey were that they liked science and they perceived themselves as 'good at science', confirms the literature that shows a strong connection between students' achievement in science, their attitudes toward science and their aspirations to further study in science (Bøe et al. 2011; Maltese \& Tai, 2010; Tytler \& Osborne, 2012). The findings are consistent with the 'within country' trends noted in the literature review that children in Australia and New Zealand who perform well in science generally have more positive attitudes toward science (Telford \& Caygill, 2007; Thomson \& De Bortoli, 2009; Thomson et al., 2007). It is evident from the findings that 'doing well in science' is an important part of having a science identity, and according to evidence collated by Bolstad and Hipkins (2008) and Tai et al. (2006), this is particularly so at the middle school level. The OECD Global Science Forum (2006) report on encouraging student interest in science and technology report recommended reformation of curriculum, particularly at the 15-year-old level, a focus on promoting equal opportunity for students and endeavouring to eliminate negative stereotypes. In this context it is important to note that nearly $90 \%$ of our respondents expressed interest in science by the time they had finished secondary school.

The findings raise interesting questions about who should be encouraged and supported to study science subjects at school and university and the best time at which this should be done. Some of the qualitative comments reflected an elitist tone, suggesting the respondents felt that science is a difficult subject only for clever people. This also was found in a study in the USA by Masnick et al. (2010). This finding contrasted with other responses that showed that some participants hadn't realised their interest in science until university or that they had 
somehow accidently fallen into a science career trajectory. Bøe et al. (2011) also note the element of chance in taking up a science career. As $86 \%$ of respondents were currently employed in a science-related field, others were studying science at postgraduate level, and even others had retired, it is evident that the people who made these comments had experienced some level of success in the science pipeline. We argue that the science community needs to reflect on this apparently elitist perception of science and broaden the way we communicate about science and scientists to be more inclusive of a greater range of people with diverse interests. We need to reflect the true nature of science as a creative, innovative field where participants are passionate and collaborative (Lunn \& Noble, 2010) in order to attract more young people into the science pipeline and to keep them there. In particular, according to Jacobs (2005), "all of us need to work together to stop the leaks in the pipeline, especially the systematic leaking of females and minorities" (p. 92) Further, the science education community many need to reconsider the degree of success a person needs in school science to participate in a science-related career. The practice in many schools in Australia of only letting students with an 'A' or 'B' grade in Year 10 science to continue studying science in upper secondary school (Venville et al., 2010), despite their interest in it, may be severely restricting the pipeline into post-secondary science education and training.

These issues bring us back to the comments from the Australian Chief Scientist, Professor Ian Chubb, quoted earlier this paper (Rowbotham, 2012). Is it too important to leave study choices to the students themselves, or is it possible to more strongly direct or encourage them to particular subjects and pathways of importance to the nation, where they are likely to find gainful employment and that may stimulate an interest in a particular field, for example, statistics or physics? Young (2008) asserted that many young people, especially those from disadvantaged backgrounds, do not have the social capital to make appropriate decisions about which subjects to study that may provide them with powerful knowledge that will allow them to move beyond the status quo of their family circumstances. Those young people may need more opportunities and encouragement during school and post-school to realise their potential. It is important that we do not inadvertently introduce curricular choices and educational practices that may limit students in their career trajectories and make becoming a scientist too difficult or too time consuming to consider. Ongoing education and advice is needed (Tytler \& Osborne, 2012) to compensate for the lack of social capital in some families to enable young people with aptitude or interest in science to follow their passions and abilities into a science career pathway. Our results show the lack of influence from school counselling on the participants' decisions to study science. This is a very practical area where improvement can be made; by providing education and information to school career counsellors it is possible that more young people can be made aware of and realise their potential to follow a science career trajectory.

\section{School experiences of science}

The findings affirmed the importance of school science, particularly secondary school science on students' subject choices. The quantitative findings indicated that participants' secondary school science experiences and also particular science teachers were the third and fourth most positive influences on their choices to study science. The implications of this finding are that if we want more students to continue with science, either to move into a science-related career or just to become more informed, scientifically literate citizens, then we have to continue to support secondary science teachers in their efforts to work with and stimulate young people, to peak their curiosity in science and involve them in challenging and engaging tasks. "If we are to enlist young people into science subjects or even sciencefriendly positions, then it will be necessary to present a richer vision of science and its value in school" (Tytler \& Osborne, 2012, p. 616). 
The Universities Australia (2012) report into the science-related attitudes of STEM and nonSTEM first year university students concluded their "key finding from the survey is the importance of teachers and the early learning experience" (p. 1). The recommendations from this report leaned heavily on the perspectives of Hoachlander and Yanofsky (2011), two leaders of a media and youth development centre in California. They argued that a much greater link between science at school and the real world was required, including a more integrated, coherent curriculum, learning by doing, project-based learning and work-based experiences to provide strong pathways into STEM-based careers. Also, like Lunn and Noble (2010), these leaders suggested closer linkage with the arts: "STEM might have more STEAM if it also paid attention to the arts" (Hoachlander \& Yanofsky, 2011, p. 65).

\section{Informal experiences of science}

The quantitative results showed interesting findings with regard to the influence of informal educational experiences of science on our respondents' choice to study science. Science television was the fifth strongest factor perceived by participants to influence their choices, with books, museums, films and science competitions reported as less important. A breakdown of the influence of these five activities by age showed that in every case their influence was strongest at the primary and lower secondary school level. Perhaps students had less time for such pursuits in senior high school. These results are supportive of the argument made by Stocklmayer et al. (2010) that greater incorporation of the informal sector can contribute positively to students' interest in and enjoyment of science. The qualitative findings revealed a number of specific informal science pursuits and activities that had influenced the participants. Indoor recreational pursuits were mentioned in the qualitative responses, including enjoying science fiction and things like chemistry sets and other sciencerelated toys. Outdoor recreational experiences also featured in the qualitative findings including farming, hiking, outdoor holidays and recreational activities. With more and more young people engaging in screen-based activities such as computer games and the internet, and the prevalence of diseases that partially result from a more sedentary lifestyle, we wonder at the impact these factors may have on future students' interests and curiosity with the world and in science. It is interesting to note that while the literature indicates that parents may have a strong influence on students' subject choices (Adamuti-Trache \& Andres, 2008), the quantitative findings from this study indicated that, retrospectively, the participating Australian and New Zealand scientists did not feel that they were particularly strongly influenced by their parents, family or friends. Fathers were considered to be between a slight and moderate positive influence and mothers only a slight positive influence on participants' choices to study science. These findings are consistent with those of Sonnert (2009) and Maltese and Tai (2010), who also found that females were more likely than males to cite parental influence. A complexity to this finding is that the qualitative findings indicated the childhood indoor and outdoor recreational habits of the participants and their families influenced their decisions about science subject choices. It seems likely that parents and the family contexts may have had an unrecognised or more subtle and less direct influence on participants' choices about science. However, we recognise that contextual factors beyond schooling will interfere with students' aspirations for a career in science. As Schoon (2001) pointed out from her longitudinal study, "Although retrospective studies account for fait accomplis, prospective longitudinal studies can uncover the drama along the way" (p. 131).

\section{Conclusion}


The participating Australian and New Zealand scientists in this study reported being strongly influenced to select science-based educational trajectories by their personal interest in science, their curiosity about the world and because they perceived that they were 'good at science'. School factors, such as secondary school science lessons and particular science teachers, influenced participants, as did their childhood recreational activities and their desire to improve the world. Factors reported to be of low influence included participants' desire to earn more money, or to increase their personal prestige, school counsellors and friends. Given these data from these science-qualified respondents, we must conclude that interest in science is clearly developed primarily during the years of schooling, and therefore an interesting and relevant science curriculum is of crucial importance in leading to science studies and science careers. This will have the added advantage of promoting science-informed citizens.

\section{Acknowledgement}

The research presented in this paper was supported by a Linkage grant from the Australian Research Council (LP0989409), with Scitech and Chevron as industry partners. The views expressed are those of the authors.

\section{References}

Abrahams, I. (2009). Does practical work really motivate? A study of the affective value of practical work in secondary school science. International Journal of Science Education, 31(17), 2335-2353.

Adamuti-Trache, M., \& Andres, L. (2008). Embarking on and persisting in scientific fields of study: Cultural capital, gender, and curriculum along the science pipeline. International Journal of Science Education, 30(12), 1557-1584.

Australian Bureau of Statistics (2011). Education and work, Australia, May 2011. Cat. no. 6227.0. Accessed 20 June 2012 from http://www.abs.gov.au

Barmby, P., Kind, P. M., \& Jones, K. (2008). Examining changing attitudes in secondary school science. International Journal of Science Education, 30(8), 1075-1093.

Bøe, M. V., Henriksen, E. K., Lyons, T., \& Schreiner, C. (2011). Participation in science and technology: Young people's achievement related choices in late-modern societies. Studies in Science Education, 47(1), 37-72.

Bolstad, R., \& Hipkins, R. (2008). Seeing yourself in science: The importance of the middle school years (Report prepared for the Royal Society of New Zealand). Wellington, New Zealand: New Zealand Council for educational Research.

Bull, A., Gilbert, J., Barwick, H., Hipkins, R. \& Baker, R. (2010). Inspired by science: A paper commissioned by the Royal Society and the Prime Minister's Chief Science Advisor. Wellington, New Zealand: New Zealand Council for Educational Research.

Bybee, R., \& McCrae, B. (2011). Scientific literacy and student attitudes: Perspectives from PISA 2006 science. International Journal of Science Education, 33(1), 7-26.

Caygill, R. (2008). Science: Trends in Year 5 science achievement 1994 to 2006. Wellington, New Zealand: Ministry of Education, New Zealand.

Cohen, L., Manion, L., \& Morrison, K. (2011). Research methods in education $\left(7^{\text {th }} \mathrm{edn}\right)$. Abingdon, UK: Routledge.

Duncan, D. B. (1955). Multiple range and multiple $F$ tests. Biometrics, 11, 1-42.

Eccles, J. (2009). Who am I and what am I going to do with my life? Personal and collective identities as motivators of action. Educational Psychologist, 44(2), 78-89. 
Education and Training Committee (ETC) Parliament of Victoria. (2006). Inquiry into the promotion of mathematics and science education. Final Report. Melbourne, Australia: Victorian Government Printer.

European Commission. (2004). Europe needs More Scientists: Report by the High Level Group on Increasing Human Resources for Science and Technology. Brussels: European Commission.

Fensham, P. J. (2008). Science education policy-making: Eleven emerging issues. Paris: UNESCO.

Fowler, F. J. (2009). Survey research methods $\left(4^{\text {th }}\right.$ edn). Thousand Oaks, CA: SAGE.

Garnett, R. (2003). Reaching all Australians. Kingston, ACT, Australia: National Reference Group.

Goodrum, D., Hackling, M., \& Rennie, L. (2001). The status and quality of teaching and learning of science in Australian schools: A research report. Canberra: Department of Education, Training and Youth affairs.

HM Treasury. (2006). Science and Innovation investment Framework: next steps. London: HMSO.

Jacobs, J. E. (2005). Twenty-five years of research on gender and ethnic differences in math and science career choices: What have we learned? New Directions for Child and Adolescent Development, no. 110, 85-94.

Hoachlander, G., \& Yanofsky, D. (2011). Making STEM real. Educational Leadership, 68(6), 60-65.

Kim, M., Song, J. (2009). The effects of dichotomous attitudes toward science on interest and conceptual understanding in physics. International Journal of Science Education, $31(7), 2385-2409$.

Lee, Y-J. (2012). Identity-based research in science education. In B. J. Fraser, K. G. Tobin \& C. J. McRobbie (Eds.), Second international handbook of science education (pp. 3545). Dordrecht, The Netherlands: Springer.

Lucas, K. (2004, June). A study of the influence of the Smart Moves presentation on students. A report prepared for Questacon: The National Science and Technology Centre, King Edward Terrace, Parkes, Canberra, Australia.

Lunn, M., \& Noble, A., (2008). Re-visioning science 'Love and passion in the scientific imagination': Art and science. International Journal of Science Education, 30(6), 793 805.

Maltese, A. V., \& Tai, R. H. (2010). Eyeballs in the fridge: Sources of early interest in science. International Journal of Science Education, 32(5), 669-685.

Masnick, A. M. Valenti, S. S., Cox, B. D., \& Osman, C. J. (2010). A multidimensional scaling analysis of students' attitudes about science careers. International Journal of Science Education, 32(5), 653-667.

Millar, R., \& Osborne, J. (2001). Beyond 2000: Science education for the future. London: King's College London.

National Academy of Sciences: Committee on Science Engineering and Public Policy. (2005). Rising Above the Gathering Storm: Energizing and Employing America for a Brighter Economic Future. Washington, DC: National Academy Sciences.

National Commission on Mathematics and Science Teaching for the 21st Century. (2000). Before It's Too Late. Washington, DC: U.S. Department of Education.

OECD Global Science Forum. (2006). Evolution of student interest in science and technology studies: Policy report. Retrieved September 3, 2006 from http://www.oecd.org/dataoecd/16/30/36645825.pdf.

Office of the Chief Scientist. 92012). Health of Australian science. Canberra, ACT: Commonwealth of Australia. www.chiefscientist.gov.au 
Osborne, J., \& Dillon, J. (2007). Research on learning in informal contexts: Advancing the field? International Journal of Science Education, 29(12) 1441-1445.

Osborne, J., Simon, S. \& Collins, S. (2003): Attitudes toward science: A review of the literature and its implications. International Journal of Science Education, 25(9), 1049-1079.

Pike, A. G., \& Dunne, M. (2011). Student reflections on choosing to study science post-16. Cultural Studies of Science Education, 6, 485-500.

Rennie, L. J. (2007). Learning science outside of school. In S. K. Abell \& N. G. Lederman (Eds.), Handbook of research on science education (pp. 125-167). Mahwah, NJ: Lawrence Erlbaum.

Riegle-Crumb, C., Moore, C., \& Ramos-Wada, A. (2011). Who wants to have a career in science or math? Exploring adolescents' future aspirations by gender and race/ethnicity. Science Education, 95(3), 458-476.

Rowbotham, J. (2012, Wednesday January 18). Gillard's chief scientists says learning crisis a 'no-brainer'". The Australian Higher Education Supplement, pp.36-37.

Schoon, I. (2001). Teenage job aspirations and career attainment in adulthood: A 17-year follow-up study of teenagers who aspired to become scientists, health professionals, or engineers. International journal of Behavioural Development, 25(2), 124-132.

Sonnert, G. (2009). Parents who influence their children to become scientists: Effects of gender and parental education. Social Studies of Science, 39(6), 927-941.

Stocklmayer, S., M., Rennie, L. J., \& Gilbert, J. K. (2010). The roles of the formal and informal sectors in the provision of effective science education. Studies in Science Education, 46, 1-44.

Tai, R. H., Liu, C. Q., Maltese, A. V., \& Fan, X. (2006). Planning early for careers in science. Science, 312, 1143-1144.

Tal, T. (2012). Out-of-school: Learning experiences, teaching and students' learning. In B. J. Fraser, K. G. Tobin \& C. J. McRobbie (Eds.), Second international handbook of science education (pp. 1109-1122). Dordrecht, The Netherlands: Springer.

Telford, M., \& Caygill, R. (2007). PISA 2006 How ready are our 15-year-olds for tomorrow's world? Wellington, New Zealand: Ministry of Education.

Thomson, S., \& De Bortoli, L. (2009). Exploring scientific literacy: How Australia measures up: The PISA 2006 survey of students' scientific, reading and mathematical literacy skills. Camberwell, Victoria: ACER Press.

Thomson, S., De Bortoli, L., Nicholas, M., Hillman, K., Buckley, S. (2011). Challenges for Australian education: Results from PISA 2009. Camberwell, Victoria: ACER Press.

Thomson, S., Wernert, N., Underwood, C., Nicholas, M. (2007). TIMSS 07: Taking a closer look at mathematics and science in Australia. Camberwell, Victoria: ACER Press.

Tytler, R. \& Osborne, J. (2012). Student attitudes and aspirations toward science. In B. J. Fraser, K. G. Tobin \& C. J. McRobbie (Eds.), Second international handbook of science education (pp. 597-626). Dordrecht, The Netherlands: Springer.

Universities Australia (2012). STEM and NonSTEM First Year Students. Canberra: Australia. Department of Industry, Innovation, Science, Research and Tertiary Education. Retrieved February 25, 2012 from www.universitiesaustralia.edu.au

Venville, G., Oliver, M., Longnecker, N., \& Rennie, L. (2010). Selecting science subjects: Why students do, why they can't! Teaching Science, 56(3), 19-26.

Wellington, J. (1990). Formal and informal learning in science: The role of interactive science centres. Physics Education, 25, 247-252.

Young, M. (2008). From constructivism to realism in the sociology of the curriculum. In G. J. Kelly, A. Luke, \& J. Green (Vol. Eds.), Review of Research in Education: What 
Counts as Knowledge in Educational Settings (Vol 32, pp. 1-28). Thousand Oaks, CA: Sage. 
Table 1: Australian and New Zealander respondents' answers to the question: "What was your age in years when you realised that you were interested in studying science?"

\begin{tabular}{lcc}
\hline Age Range in Years & $\%$ & Cumulative \% \\
\hline Under 9 & 12.0 & 12.0 \\
9 to 11 & 12.8 & 24.9 \\
12 to 14 & 25.7 & 50.6 \\
15 to 17 & 38.5 & 89.1 \\
18 to 20 & 6.4 & 95.4 \\
21 to 25 & 2.3 & 97.8 \\
26 to 30 & 1.7 & 99.4 \\
31 and over & 0.6 & 100.0 \\
\hline
\end{tabular}




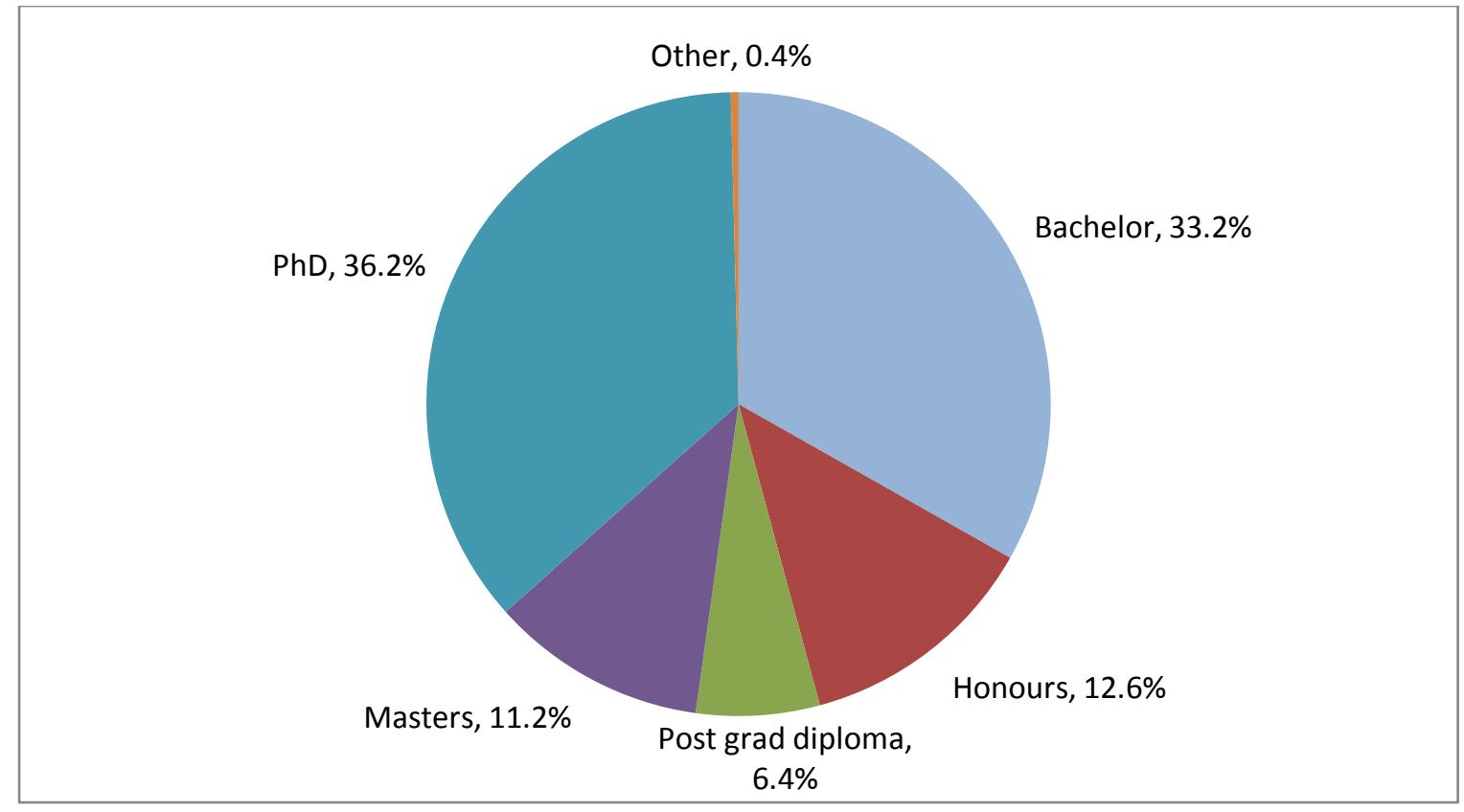

Figure 1: The highest qualification of survey respondents $(n=726)$.

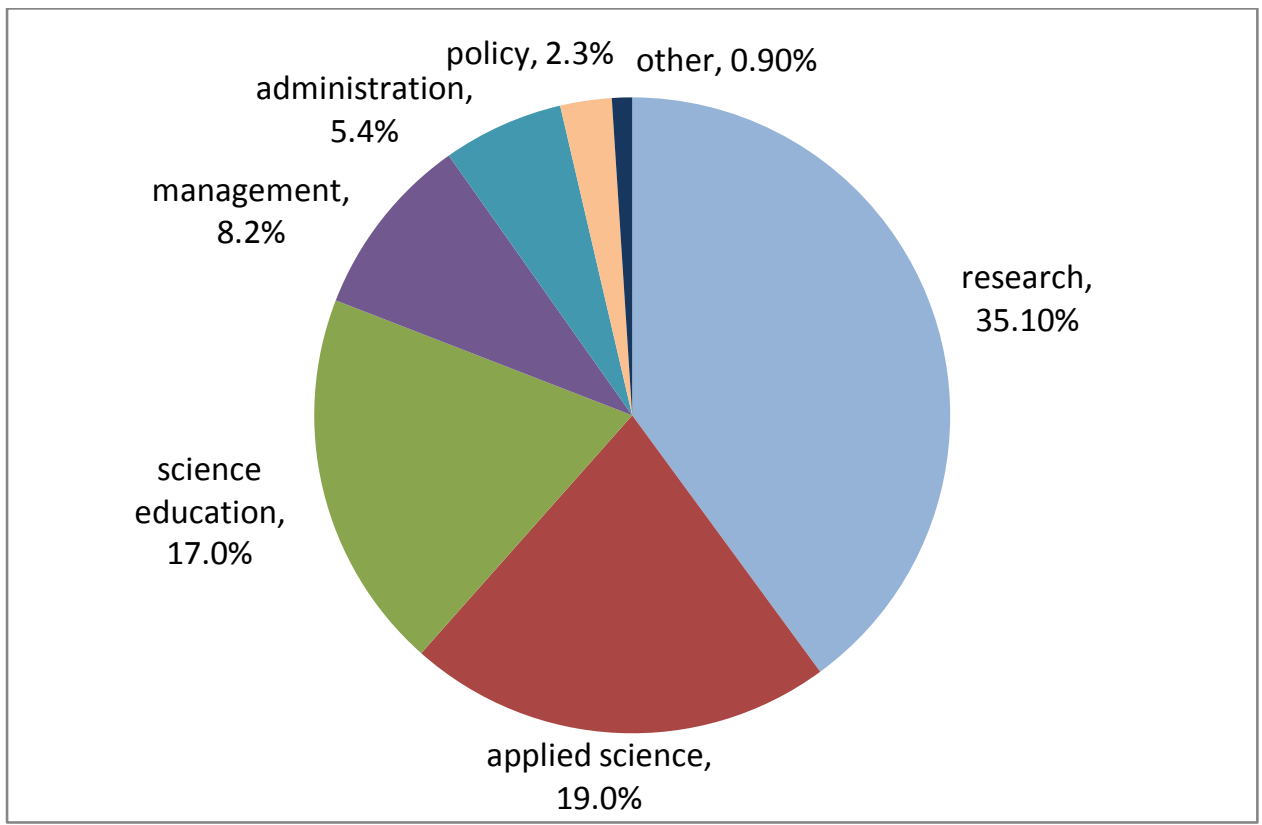

Figure 2: Science work types of the $86.3 \%$ of respondents who were currently employed in science-related fields $(n=623)$. 


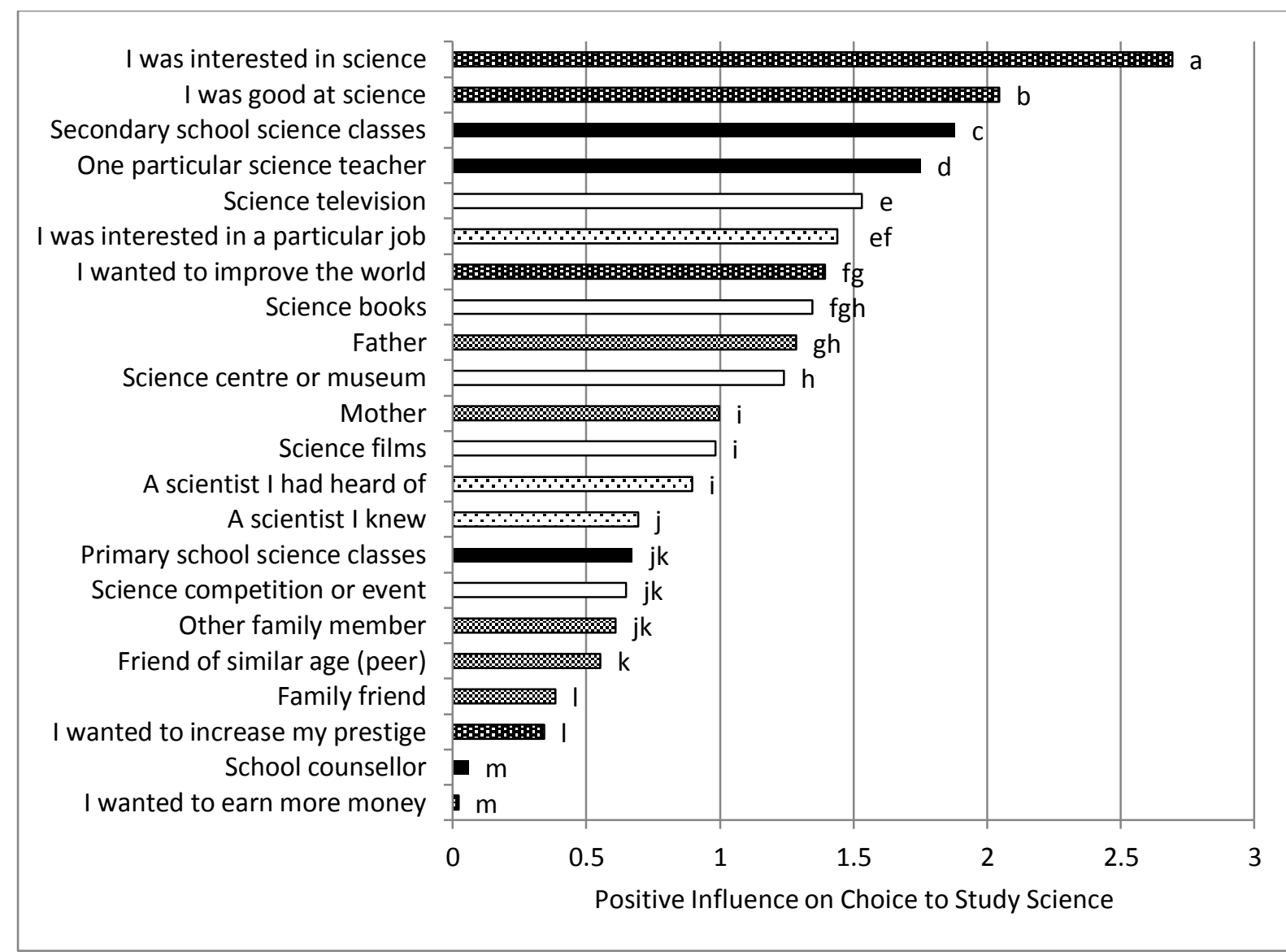

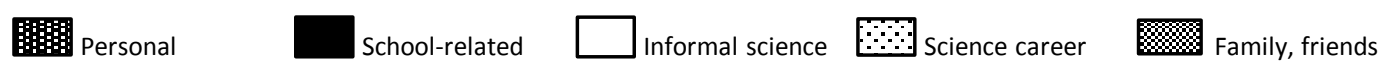

Figure 3: Mean scores of respondents to the 22 Likert questions concerning the reasons they chose to study science. A score of 0 is no influence; 1 is slight influence; 2 moderate influence; and 3 is strong influence. Different letters indicate statistically significant difference in mean scores for those items ( $p<0.05$ for Duncan's multiple range test). 


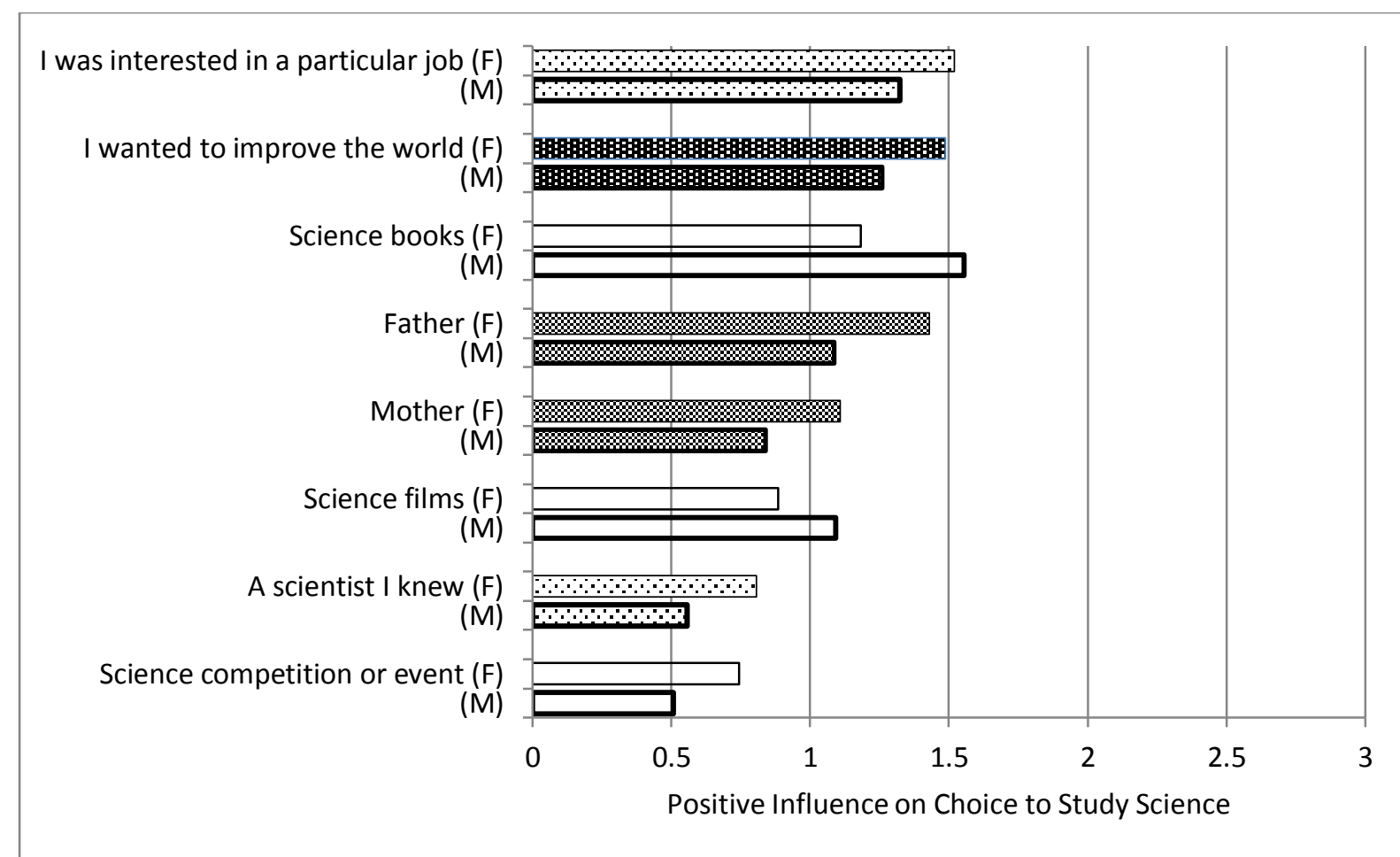

Figure 4: Mean scores of female (F) and male (M) respondents to eight Likert questions concerning the reasons they chose to study science. A score of 0 is no influence; 1 is slight influence; 2 moderate influence; and 3 is strong influence. 


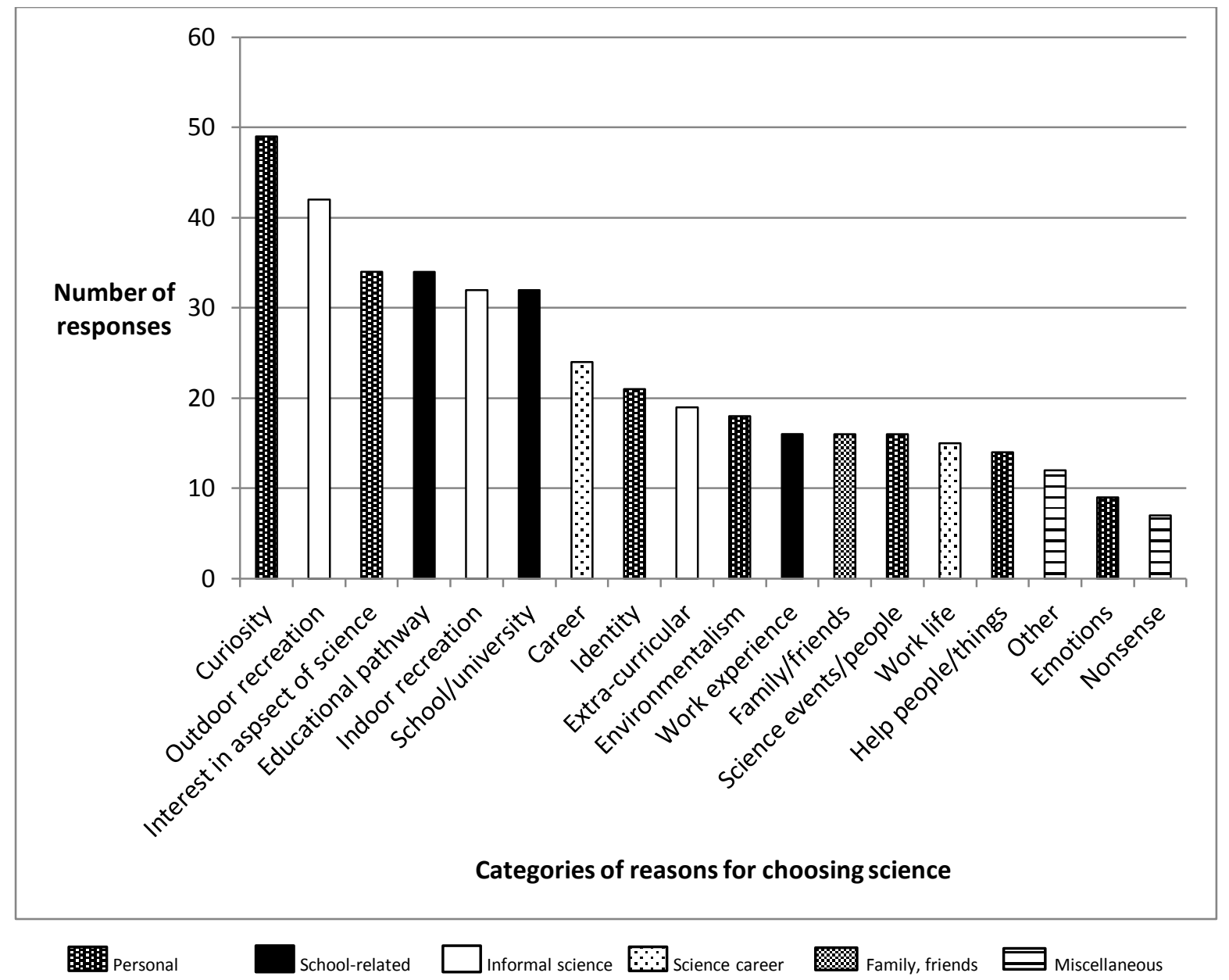

Figure 5: Numbers of responses under each category from the participants' responses to the question "Was there an important influence on you to study science that was not covered in the series of questions above?" The total number of responses was 404 from 219 of the 722 participants. 
Appendix 1: Coding manual for the responses to the question "Was there an important influence on you to study science that was not covered in the series of questions above?"

\begin{tabular}{|c|c|c|}
\hline Category of Responses & Description of Category & Examples of Responses in this Category \\
\hline \multicolumn{3}{|l|}{ PERSONAL } \\
\hline $\begin{array}{l}\text { A } \\
\text { Curiosity/inquiry/intelligence with } \\
\text { regard to the nature of science }\end{array}$ & $\begin{array}{l}\text { Participants give curiosity related reasons for pursuing } \\
\text { science, for example curiosity, fascination, because they } \\
\text { wanted to know how things worked, that science is } \\
\text { intellectually stimulating, truthful or an easy or } \\
\text { challenging subject. }\end{array}$ & $\begin{array}{l}\text { - A pure curiosity to understand the world around me } \\
\text { - I wanted to know how the world worked } \\
\text { - I wanted to know how things worked, especially biological } \\
\text { - Possessing an inquiring mind } \\
\text { - An interest in correctness and precision }\end{array}$ \\
\hline $\begin{array}{l}\text { B } \\
\text { Interest in particular science topics } \\
\text { or aspects of science }\end{array}$ & $\begin{array}{l}\text { Participants mention a particular science topic, such as } \\
\text { maths, physics, chemistry, plants, animals, insects, or } \\
\text { aspect of science as their main reason for pursuing } \\
\text { science. }\end{array}$ & $\begin{array}{l}\text { - An interest in natural history, especially invertebrates } \\
\text { - I liked flowers and studied Botany } \\
\text { - I liked mathematics } \\
\text { - experiments } \\
\text { - precision }\end{array}$ \\
\hline $\begin{array}{l}\text { C } \\
\text { Identity }\end{array}$ & $\begin{array}{l}\text { Participants refer to seeing themselves or that other } \\
\text { people saw them as a science type person, or that their } \\
\text { characteristics aligned with the nature of science. }\end{array}$ & $\begin{array}{l}\text { - innate abilities } \\
\text { - my desire } \\
\text { - Math was my way to be different from the crowd } \\
\text { - Science was considered as the subject for intelligent students }\end{array}$ \\
\hline $\begin{array}{l}\text { D } \\
\text { Environmentalism }\end{array}$ & $\begin{array}{l}\text { Participants mention something related to } \\
\text { environmentalism as a reason for pursuing science such } \\
\text { as a concern for the environment, global warming, } \\
\text { climate change, endangered species and habitat } \\
\text { destruction. }\end{array}$ & $\begin{array}{l}\text { - Concern for the environment } \\
\text { - Biodiverse environment } \\
\text { - Climate change emerged as a major threat } \\
\text { - Environmental issues and problems }\end{array}$ \\
\hline $\begin{array}{l}\text { E } \\
\text { Science/Natural Events/particular } \\
\text { scientists }\end{array}$ & $\begin{array}{l}\text { Participants refer to a natural or science/technology } \\
\text { event, such as Halley's Comet, Apollo landing, or a } \\
\text { tsunami or a particular scientist that influenced them } \\
\text { into a science pathway. }\end{array}$ & $\begin{array}{l}\text { - Big Bang } \\
\text { - Publicity of results from US space program - esp Viking and } \\
\text { Voyager spacecraft } \\
\text { - The Apollo Moon landings } \\
\text { - Experiencing weather events } \\
\text { - Richard Dawkins }\end{array}$ \\
\hline $\begin{array}{l}\text { F } \\
\text { Help People/Improve world }\end{array}$ & $\begin{array}{l}\text { Participants refer to helping people or children or } \\
\text { improving the world as a main reason for pursuing }\end{array}$ & $\begin{array}{l}\text { - Being part of a solution to malaria in Africa } \\
\text { - Death in family-interest in Medical Science }\end{array}$ \\
\hline
\end{tabular}




\begin{tabular}{|c|c|c|}
\hline & $\begin{array}{l}\text { science. They may have had sickness or death in the } \\
\text { family or needed/wanted to improve their family } \\
\text { circumstances or their country. }\end{array}$ & $\begin{array}{l}\text { - My Mum's medical case } \\
\text { - Wanted to help people that were sick } \\
\text { - to improve farming techniques }\end{array}$ \\
\hline $\begin{array}{l}\text { G } \\
\text { Emotion/passion }\end{array}$ & $\begin{array}{l}\text { Participants mention emotions such as enjoyment, fun, } \\
\text { passion, excitement, love, like and interest as a primary } \\
\text { reason for pursuing science. }\end{array}$ & $\begin{array}{l}\text { - Chemistry was exciting } \\
\text { - Always fascinated by nature } \\
\text { - I liked it } \\
\text { - I enjoyed it } \\
\text { - Childhood love of natural history }\end{array}$ \\
\hline \multicolumn{3}{|l|}{ INFORMAL SCIENCE } \\
\hline $\begin{array}{l}\text { H } \\
\text { Outdoor recreation/lifestyle } \\
\text { upbringing or pursuits }\end{array}$ & $\begin{array}{l}\text { Participants mention recreational pursuits such as } \\
\text { camping, fishing, hiking, holidays, star gazing, or places } \\
\text { such as the beach, mountains, family farm as a reason } \\
\text { for pursuing science. }\end{array}$ & $\begin{array}{l}\text { - Brought up on a farm } \\
\text { - Beautiful wildlife in Africa where I grew up } \\
\text { - Camping as a child } \\
\text { - Sailing a yacht for a year to the Caribbean and back }\end{array}$ \\
\hline $\begin{array}{l}\text { Indoor recreational/lifestyle } \\
\text { pursuits }\end{array}$ & $\begin{array}{l}\text { Participants mention recreational/lifestyle pursuits such } \\
\text { as radio, science fiction, podcasts, science toys, books, } \\
\text { or other hobby as a reason for pursuing science. }\end{array}$ & $\begin{array}{l}\text { - I was given a slide rule as a gift } \\
\text { - Podcasts (Skeptics Guide to the Universe) } \\
\text { - Science books magazines } \\
\text { - Science fiction }\end{array}$ \\
\hline $\begin{array}{l}\text { J Extra-curricular, organised } \\
\text { activities from educational } \\
\text { provider }\end{array}$ & $\begin{array}{l}\text { Participants mention extra-curricular, organised } \\
\text { educational activities such as clubs, summer camp, } \\
\text { museum, science centres or scouts as their main reason } \\
\text { for pursuing science. }\end{array}$ & $\begin{array}{l}\text { - An after-school science club } \\
\text { - Boy Scout \& Explorer experience } \\
\text { - Early visits to local observatory }\end{array}$ \\
\hline \multicolumn{3}{|l|}{ SCHOOL RELATED } \\
\hline $\begin{array}{l}\text { K } \\
\text { Educational Pathway }\end{array}$ & $\begin{array}{l}\text { Participants refer to their educational pathway as a } \\
\text { reason for pursuing science. E.g. they had no choice; } \\
\text { they specialized early in science, they weren't good at } \\
\text { other subjects, they wanted to do something/a job that } \\
\text { required science, or science was a second choice. }\end{array}$ & $\begin{array}{l}\text { - I wanted to be a vet and science is required } \\
\text { - I wasn't keen on languages or the arts } \\
\text { - I was not competitive for medical school/lost interest in medicine } \\
\text { - To specialize in science journalism }\end{array}$ \\
\hline $\begin{array}{l}\mathrm{L} \\
\text { School/university }\end{array}$ & $\begin{array}{l}\text { Participants mention something related to school or } \\
\text { university such as a particular lecture or teacher, a } \\
\text { textbook, that they liked school and that influenced } \\
\text { their decision to follow science. }\end{array}$ & $\begin{array}{l}\text { - A lecturer at University } \\
\text { - One science Lecture at University } \\
\text { - Physics/Math teacher } \\
\text { - My teachers' believe in my ability to do great } \\
\text { - Science program of a compulsory class at high school }\end{array}$ \\
\hline
\end{tabular}




\begin{tabular}{|c|c|c|}
\hline $\begin{array}{l}\text { M } \\
\text { Work experience/internships }\end{array}$ & $\begin{array}{l}\text { Participants refer to work experience or a school or } \\
\text { university internship that influenced them to pursue } \\
\text { science. }\end{array}$ & $\begin{array}{l}\text { - Cartography/geosciences internship in high school } \\
\text { - Once I started my degree work experience } \\
\text { - Performing science support activities for work \& being exposed } \\
\text { via activity and proximity } \\
\text { - Summer job at a lab }\end{array}$ \\
\hline \multicolumn{3}{|l|}{ SCIENCE CAREER } \\
\hline $\begin{array}{l}\mathrm{N} \\
\text { Career }\end{array}$ & $\begin{array}{l}\text { Participants mention career or employment reasons } \\
\text { such as job availability, employment prospects, or the } \\
\text { need for women in science, or the desire not to do } \\
\text { another type of job as a reason for pursuing a science } \\
\text { pathway. }\end{array}$ & $\begin{array}{l}\text { - Availability of employment opportunities } \\
\text { - Avoid a boring job } \\
\text { - No available job supply in China, only continue my study in } \\
\text { Science } \\
\text { - Need more women in science }\end{array}$ \\
\hline $\begin{array}{l}\text { O } \\
\text { Science work/lifestyle }\end{array}$ & $\begin{array}{l}\text { Participants refer to the nature of the type of work or } \\
\text { lifestyle that scientists do that influenced them into a } \\
\text { science pathway. For example, lab work, travel, } \\
\text { experiments, adventure, science equipment, or the } \\
\text { power of doing research. }\end{array}$ & $\begin{array}{l}\text { - Opportunities to engage in research that requires fieldwork } \\
\text { - Practical based } \\
\text { - I wanted to leave New Zealand } \\
\text { - life style - strong interaction with the sea \& bushland }\end{array}$ \\
\hline \multicolumn{3}{|l|}{ FAMILY, FRIENDS } \\
\hline $\begin{array}{l}\mathrm{P} \\
\text { Family/friends }\end{array}$ & $\begin{array}{l}\text { Participants refer to family members such as } \\
\text { grandparents or peers who put them under pressure or } \\
\text { did things that made them interested in pursuing } \\
\text { science. }\end{array}$ & $\begin{array}{l}\text { - My grandmother } \\
\text { - Parents influence was just due to Societal influence } \\
\text { - Family discussions } \\
\text { - The love of my grandfather for mathematics. He was always } \\
\text { motivating his grandsons to be good in mathematics with different } \\
\text { card plays and chess } \\
\text { - family of origin social exclusion }\end{array}$ \\
\hline \multicolumn{3}{|l|}{ MISCELLANEOUS } \\
\hline $\begin{array}{l}\text { Q } \\
\text { Other }\end{array}$ & $\begin{array}{l}\text { Any factors the participants mention that do not readily } \\
\text { fit into one of the other categories. For example, } \\
\text { religion, chance and popularity }\end{array}$ & $\begin{array}{l}\text { - Christian conviction } \\
\text { - Availability of a scholarship } \\
\text { - chance } \\
\text { - society }\end{array}$ \\
\hline $\begin{array}{l}\mathrm{R} \\
\text { Nonsense }\end{array}$ & Entries that don't make any sense & $\begin{array}{l}\text { - Why did they do it? } \\
\text { - Out on a limb }\end{array}$ \\
\hline
\end{tabular}

